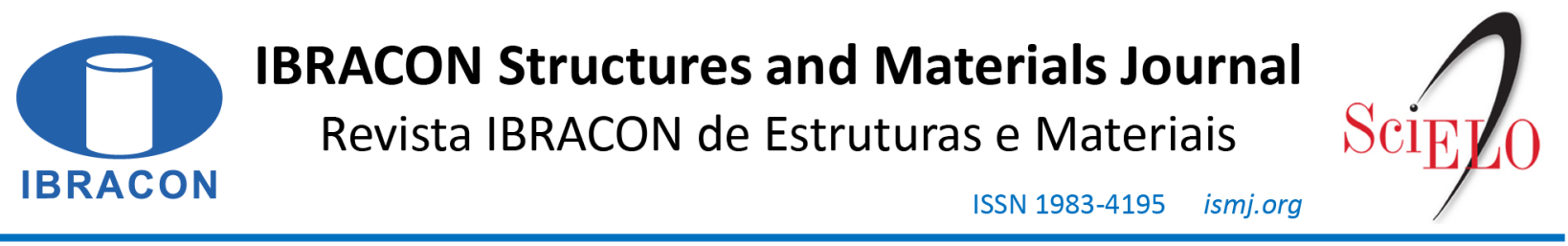

ORIGINAL ARTICLE

\title{
Effect of the connecting beam stiffness on the bracing limit for reinforced concrete slender columns in single and multi-story frames
}

\author{
Efeito da rigidez do feixe de conexão no limite de preparação para colunas esbeltas \\ de concreto armado em quadros únicos e multi-andares \\ Mohamed Gamal Aboelhassan ${ }^{\mathrm{a}}$ (D) \\ Mohie Eldin Shoukrya \\ Said Mohamed Allam ${ }^{\mathrm{a}}$

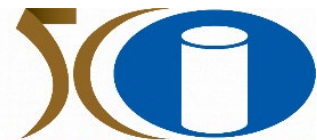 \\ YEARSIBRACON
}

${ }^{a}$ Alexandria University, Faculty of Engineering, Department of Structural Engineering, Alexandria, Egypt

Received: 20 June 2021

Accepted: 31 August 2021

\begin{abstract}
The main purpose of this paper is to study analytically the behavior of slender reinforced concrete columns existing in sway and non-sway structures. The studied variables were the stiffness of the beam connected to the slender columns, the stiffness of the bracing columns, and the number of bays and stories in the structure model. The stability of slender columns was studied and the required limits for the lateral bracing were determined using a finite element program to perform buckling analysis, linear analysis, and geometric nonlinear analysis for the different frame structural models. All the results obtained in this study were compared to the available methods included in the different building codes and the methods suggested by other researchers. The results indicated that the minimum value of the bracing limit, required to restrain the slender column against the side-sway, depends on the stiffness of the connecting beams, number of stories, and number of bays. The required bracing limit decreases with increasing the beam stiffness and with increasing the number of bays. However, the required bracing limit increases with the increase of the number of stories in the structure.
\end{abstract}

Keywords: slender columns, reinforced concrete, beam stiffness, buckling analysis, geometric nonlinearity.

Resumo: O objetivo principal deste artigo é estudar analiticamente o comportamento de pilares esbeltos de concreto armado em estruturas deslocáveis e não deslocáveis. As variáveis estudadas foram a rigidez da viga conectada aos pilares esbeltos, a rigidez dos pilares de contraventamento e o número de vãos e andares no modelo de estrutura. A estabilidade de pilares esbeltos foi estudada e os limites exigidos para o contraventamento lateral foram determinados usando um programa de elementos finitos para realizar análise limite de flambagem, análise linear, e análise não linear geométrica para os diferentes modelos estruturais de pórticos. Todos os resultados obtidos neste estudo foram comparados com os métodos disponíveis incluídos nas diferentes normas de construção civil e os métodos sugeridos por outros pesquisadores. Os resultados indicaram que o valor mínimo do limite de contraventamento, necessário para restringir o pilar esbelto contra a deslocabilidade lateral, depende da rigidez das vigas de conexão, número de andares e número de vãos. O limite de contraventamento necessário diminui com o aumento da rigidez da viga e com o aumento do número de vãos. No entanto, o limite de contraventamento necessário aumenta com o aumento do número de andares na estrutura.

Palavras-chave: pilares esbeltos, concreto armado, rigidez de viga, análise de flambagem, não linearidade geométrica.

How to cite: M. G. Aboelhassan, M. E. Shoukry, and S. M. Allam "Effect of the connecting beam stiffness on the bracing limit for reinforced concrete slender columns in single and multi-story frames," Rev. IBRACON Estrut. Mater., vol. 15, no. 2, e15209, 2022,

https://doi.org/10.1590/S1983-41952022000200009 


\section{INTRODUCTION}

Reinforced concrete framed structures might fail by lateral instability caused by excessive inter-story drift, particularly when subjected to extreme earthquake motions. More than 200 years ago, Euler demonstrated that a long, straight, pin-jointed, and concentrically loaded column would remain stable until a critical load is reached at which lateral deflection increases rapidly with a small amount of increase in axial load. For a column with different boundary conditions, the critical buckling load is expressed by Equation 1 (which is a modification of the well-known Euler's equation). The degree of slenderness in a column is expressed in terms of slenderness ratio; $\lambda$ as defined in Equation 2.

$P_{c r}=\frac{\pi^{2} E I}{\left(l_{\text {eff }}\right)^{2}}$

$\lambda=\frac{l_{e f f}}{i}=\frac{K l_{u}}{i}, i=\sqrt{I / A}$

where, $\mathrm{P}_{\text {cr }}$ is the critical buckling load, EI is the bending stiffness of the column in the direction under consideration, $l_{\text {eff }}$ is the effective buckling length of the column, $l_{\mathrm{u}}$ is the unsupported column length (or clear length), $\mathrm{K}$ is the effective length factor reflecting end restraint and lateral bracing conditions of a column which expressed by the parameter $\psi$ in Equation $6, i$ is the radius of gyration reflecting the area and shape of a column cross-section, $I$ is the cross-sectional moment of inertia, and $\mathrm{A}$ is the cross-sectional area.

MacGregor [1] showed that for the same reinforced concrete cross-section, different types of failure could happen as shown in Figure 1. Failure of a slender column is initiated by the material failure of a section, or the instability failure of the column, depending on the level of slenderness ratio of the column and its end restraints. In the case of instability failure, buckling occurs in columns, and failure is reached before material failure and develops at any cross-section along the column. Large values of lateral deformations are observed with a slight increase in axial load acting on the column. This type of failure can only occur with columns of high values of slenderness ratio.

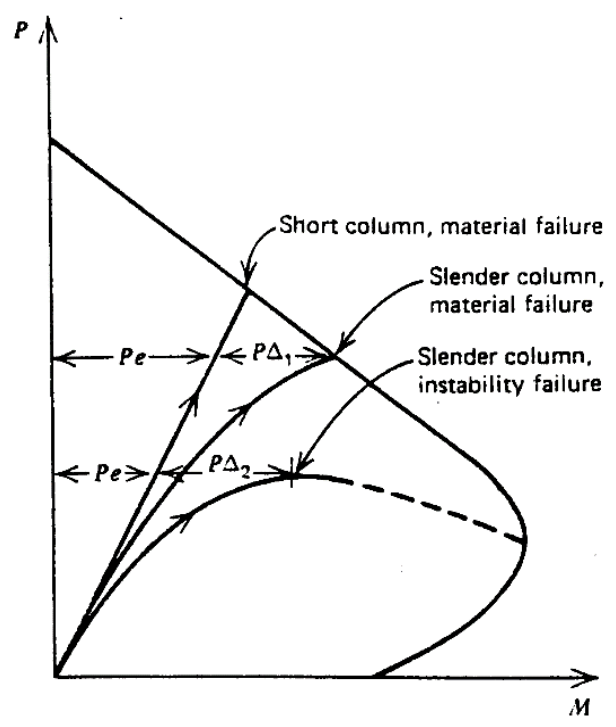

Figure 1. Types of failure for reinforced concrete columns [1].

Structures or structural members may be classified as braced or unbraced depending on the provisions or not of bracing elements and as non-sway or sway depending on their sensitivity to second-order effects due to lateral deflections. According to ACI 318-14 [2], It shall be permitted to assume a column in a structure is non-sway if the 
increase in column end moments due to second-order effects ( $\mathrm{P}-\Delta$ effect) does not exceed $5 \%$ of the first order end moments as given by Equation 3 introduced by MacGregor and Hage [3]. However, according to the Egyptian code (ECP 203-2018) [4] and the British Standards (BS 8110-97) [5], a building is considered non-sway if it has lateral stiffness of bracing elements. The bracing element should be continuous at the whole height of the building and should be symmetrically arranged in the plan, and completely fixed to the foundations. The bracing elements should satisfy the criteria in Equations 4 and 5.

$Q=\frac{\sum P_{u} \Delta_{0}}{H_{u} l_{c}} \leq 0.05$

Where, $\mathrm{Q}$ is the stability index for the building, $\Sigma \mathrm{P}_{\mathrm{u}}$ is the total factored vertical load on all columns of the story, $\mathrm{H}_{\mathrm{u}}$ is the story shear, respectively, $l_{\mathrm{c}}$ is the length of compression member in a frame, measured from center to center of the joints in the frame, and $\Delta_{\mathrm{o}}$ is the first-order relative deflection between the top and bottom of that story due to $\mathrm{H}_{\mathrm{u}}$.

$$
\begin{array}{lr}
\alpha=H_{b} \sqrt{\frac{N}{\Sigma E I}}<0.2+0.1 n & (\text { for a building less than } 4 \text { stories }) \\
\alpha=H_{b} \sqrt{\frac{N}{\Sigma E I}}<0.6 \quad & \text { (for a building 4 stories or more) }
\end{array}
$$

Where, $\mathrm{H}_{\mathrm{b}}$ is the total height of the building above foundations, $\mathrm{N}$ is the sum of the vertical loads acting on the building, $\sum E I$ is the sum of flexural rigidities of all vertical bracing elements acting in the direction considered, and $n$ is the number of stories in the building.

According to the commentary of ACI 318-14 [2], the effective length factor K may be taken as the smaller of Equations 7 and 8 for compression members in non-sway frames, which were first suggested by Cranston [6]. However, for sway frames, the effective length factor K may be taken from Equations 9 and 10 developed by Furlong [7]. In the Egyptian code (ECP 203-2018) [4] and the British Standards (BS 8110-97) [5], the effective length factor K is as given by Equations 7 and 8 for braced columns, and by Equations 11 and 12 introduced by Cranston [6] for unbraced columns. Also, the American Institute of Steel Construction (ANSI/AISC 360-16) [8] introduced a general formula for the Kfactor as shown in Equation 13 .

$$
\begin{aligned}
& \Psi=\frac{\sum\left(E I_{c} / l_{c}\right)}{\sum\left(E I_{b} / l_{b}\right)} \\
& \mathrm{K}=0.70+0.05\left(\Psi_{1}+\Psi_{2}\right) \leq 1.0 \\
& \mathrm{~K}=0.85+0.05\left(\Psi_{\min }\right) \leq 1.0 \\
& \mathrm{For} \Psi_{m}<2 \quad \mathrm{~K}=\frac{20-\Psi_{m}}{20} \sqrt{1+\Psi_{m}} \\
& \text { For } \Psi_{m} \geq 2 \quad \mathrm{~K}=0.90 \sqrt{1+\Psi_{m}} \\
& \mathrm{~K}=1.0+0.15\left(\Psi_{1}+\Psi_{2}\right) \geq 1.0 \\
& \mathrm{~K}=2.0+0.3\left(\Psi_{\min }\right) \geq 1.0
\end{aligned}
$$


$K_{2}=\sqrt{\frac{P_{\text {story }}}{P_{r}} \times \frac{I_{i}}{\sum\left(I_{i} / K_{n 2}^{2}\right)}} \geq \sqrt{\frac{5}{8}} \times K_{n 2}$

where, $\psi$ is the end restraint of the column, $\mathrm{EI}_{\mathrm{c}}$ is the bending stiffness of column in direction under consideration, $\mathrm{EI}_{\mathrm{b}}$ is the bending stiffness of beam in direction under consideration, $l_{c}$ is the height of column measured between centers of restraints, $l_{b}$ is the span length of the beam measured center to center of joints, the symbol $\Sigma$ indicates the summation for all members stiffness connected at the joint and lying in the plane at which buckling of the column is being considered, $\Psi_{1}$ and $\Psi_{2}$ are the values of $\Psi$ at the two ends of the column, $\Psi_{\min }$ and $\Psi_{\mathrm{m}}$ are the smaller and the average values of the two ends of the column, respectively, $K_{2}$ is the modified effective length factor for $i^{\text {th }}$ rigid partially braced column, $I_{i}$ is the moment of inertia in plane of bending for $i^{\text {th }}$ rigid column, $K_{n 2}$ is the effective length factor for $i^{\text {th }}$ rigid column based on classic alignment charts, $P_{r}$ is the required axial compressive strength for $i^{\text {th }}$ rigid column, and $P_{\text {story }}$ is the total axial loads of the story.

On the other hand, Aristizabal-Ochoa [9], [10] presented a practical approach to calculating the effective length factor for a single column as well as for a multi-column system. In multi-column systems with side-sway uninhibited or partially inhibited, every column is defined as having reached its critical load when side-sway buckling of the frame occurs, the load distribution among the columns is as specified by the designer. In this approach, the effective length factor of each column is a function of its properties, the properties of the entire frame, and the distribution of loads among the columns in the frame. Hellesland and Bjorhovde [11] introduced an improved method to calculate the effective length factor and, at the same time, the method satisfies general system instability for the whole structure. The primary attention in that study was concentrated on non-sway structures. The effective length factors for all columns are first calculated using traditional methods. These values are then used as input data to obtain the modified effective length factors. Furthermore, Bendito et al. [12] developed an equation to calculate the effective length factor for reinforced concrete columns considering the geometric and the material nonlinear performance of these columns. Ma et al. [13] presented another method to calculate the effective length of slender columns elastically restrained at the column top and fixed at the base using the ANSYS program to perform buckling analysis of a slender reinforced concrete column on the bottom floor. Results proved that the obtained effective length factor based on this method was higher than the design code by more than $20 \%$. On the other hand, Farouk [14] suggested an approximate equation to calculate the additional moment for braced slender columns in the elastic analysis. The additional moment calculated from this equation and the finite element analysis showed a good agreement. Marí and Hellesland [15] derived analytical expressions for the lower slenderness limits of reinforced concrete columns with different reinforcement distributions. Excellent agreement was found between the numerical results and those obtained by the proposed expression. Fawzy [16] carried out an analytical study considering the nonlinear material and geometric analyses to determine the sufficient lateral stiffness required to ensure full bracing conditions in one-story frame structures. For a single-bay, single-story frame, beams of high moment of inertia can possess a full fixation for columns and thus increase the critical buckling loads for these columns, this increase was found to be from three to five times of the corresponding buckling loads obtained for the same column when it is free to rotate at its end joints. However, the required lateral stiffness of a bracing column, given as a ratio of the sum of stiffness of other columns in the story, decreases with increasing the number of bays of structure and increases with increasing number of stories of structure. Khuntia and Ghosh [17], [18] introduced an analytical and the experimental research. Which stated that the moment of inertia for column is independent of the reinforcement ratio $\rho$, the axial load $\mathrm{P}$, the eccentricity ratio e/h (bending moment to axial load ratio), and the compressive strength of concrete $f_{c}^{\prime}$. Similarly, the moment of inertia for beams does not take the effect of reinforcement ratio $\rho_{\mathrm{g}}$ into account. This simplification may not be appropriate in many practical cases. Analysis shows that the column inertia can vary from $0.5 \mathrm{I}_{\mathrm{g}}$ to $1.0 \mathrm{I}_{\mathrm{g}}$ and the beam inertia from $0.3 \mathrm{I}_{\mathrm{g}}$ to $0.5 \mathrm{I}_{\mathrm{g}}$ in $\mathrm{most}$ practical cases. Based on the results, it was recommended that the effective EI of beams and columns to be used in the lateral analysis of frames in general and of frames including slender columns.

\section{RESEARCH OBJECTIVE}

The restraining effect of beams has a major effect on slender column behavior, such as limiting the horizontal displacement resulting from lateral loads. Also, there is no clear and definite criterion available to determine the necessary and sufficient required stiffness for the bracing elements to guarantee a full non-sway condition. The main objective of this study is: 
(1) To study the effect of beam stiffness on the required limits for the lateral stiffness of the bracing elements. This limit is called the bracing limit and it is defined as the stiffness of the bracing element above which the structure can be considered a non-sway structure.

(2) To obtain the effect of the increasing number of bays and number of stories of the structure on the required bracing limit.

In the current analytical study, many variables were considered which affecting the stability of structures. These variables were:

- The beam stiffness connecting to the slender columns.

- The stiffness of the bracing column.

- The number of bays and stories in the structural frame model.

It should be noted that as stated in the analytical study conducted by Fawzy [16], the value of the horizontal loads, applied on the studied frames, did not affect the critical buckling loads of the slender columns. Therefore, the presence of horizontal loads was ignored in the current analytical study. Also, to ensure the accuracy of the current buckling model was verified with the nonlinear material and geometric model presented by Fawzy [16] and the obtained results were very similar. The buckling analysis was selected to reduce the time of solving the model in the computer program.

\section{STABILITY MODEL}

In the current analytical study, eigenvalue buckling analyses were performed using ANSYS software. Generally, the ANSYS program includes models to solve linear and nonlinear static and dynamic structural problems [19]. A twodimensional beam element (BEAM3) was used for modeling the frame members. BEAM3 is a uni-axial element with tension, compression, and bending capabilities for two-dimensional structural models. The element has three degrees of freedom at each node; translations in the nodal $\mathrm{x}$ and $\mathrm{y}$ directions and rotation about the nodal z-axis. After performing linear and nonlinear analysis, the output results for this element for geometric nonlinear analysis can be read in the form of axial forces, moments, shears, displacements, deformed shapes, and stresses in the element local coordinate system. However, the output results for this element for buckling analysis can be read in the form of the critical axial buckling load. The buckling problem is formulated as an eigenvalue problem, see Equation 14. It should be noted that the ANSYS program used some assumptions and restrictions for the buckling analysis which were:

(1) The analysis is valid for structural degrees of freedom only.

(2) The structure fails suddenly with a horizontal force-deflection curve.

(3) The structure has constant stiffness effects.

(4) A static solution with pre-stressed effects included was run.

$\left([K]+\lambda_{i}[S]\right)\{\Psi\}_{i}=\{0\}$

where, $[\mathrm{K}]$ is the stiffness matrix, $[\mathrm{S}]$ is the stress stiffness matrix, $\lambda_{\mathrm{i}}$ is the $\mathrm{i}^{\text {th }}$ eigenvalue used to multiply the loads generated $[\mathrm{S}]$, and $\{\psi\}_{\mathrm{i}}$ is the $\mathrm{i}^{\text {th }}$ eigenvector of displacements. The eigenvectors are normalized so that the largest component is 1 . Thus, the stresses (when output) may only be interpreted as a relative distribution of stresses. If the first eigenvalue closest to the shift point is negative (indicating that the loads applied in a reverse sense will cause buckling), the program will terminate.

Figure 2 presents the frame model used in the analysis. This two-dimensional frame model consisted of a slender column with inertia $I_{o}$ and a bracing column with inertia $\mathrm{I}_{\mathrm{br}}$. Each column was completely fixed at its bottom end and was restrained at the top end by a horizontal beam with inertia $\mathrm{I}_{\mathrm{b}}$. Several cases were studied by increasing the moment of inertia of the bracing column, in each case, as a ratio of the moment of inertia of the slender column according to a specified value of beam moment of inertia. Bucking analysis was performed for each case by applying a unit vertical load at each column. The unit vertical load was applied equally to all floors for the multi-story model. The obtained values of critical buckling loads for the sway frame model (Figure 2a) were compared, for each case, with the corresponding values obtained for the same model when being completely restrained against side-sway (Figure $2 b$ ). To ensure that the buckling occurs in columns and the instability failure is reached before the material failure, the dimension of the story height was selected to have a column with high values of slenderness ratio which is not accepted by most building codes.

In the current analytical study, the minimum amount of stiffness of the bracing columns for which the critical buckling load of the slender column reaches $95 \%$ of the corresponding value obtained when the same structure is 
completely restrained against side-sway is defined as the bracing limit according to ACI 318-14 [2]. This minimum required stiffness is introduced as a ratio between the stiffness of the bracing column to that of the slender column $\left(\mathrm{I}_{\mathrm{br}} / \mathrm{I}_{\mathrm{o}}\right)$ or as a ratio between the stiffness of the bracing column to the sum of all other slender columns forming the structure for multi-bay frames $\left(\mathrm{I}_{\mathrm{br}} / \Sigma \mathrm{I}_{\mathrm{o}}\right)$. Also, multi-story, multi-bay frames with 1, 2, and 3 stories or/and 1, 2, and 3 bays were analyzed, as shown in Figure 3.
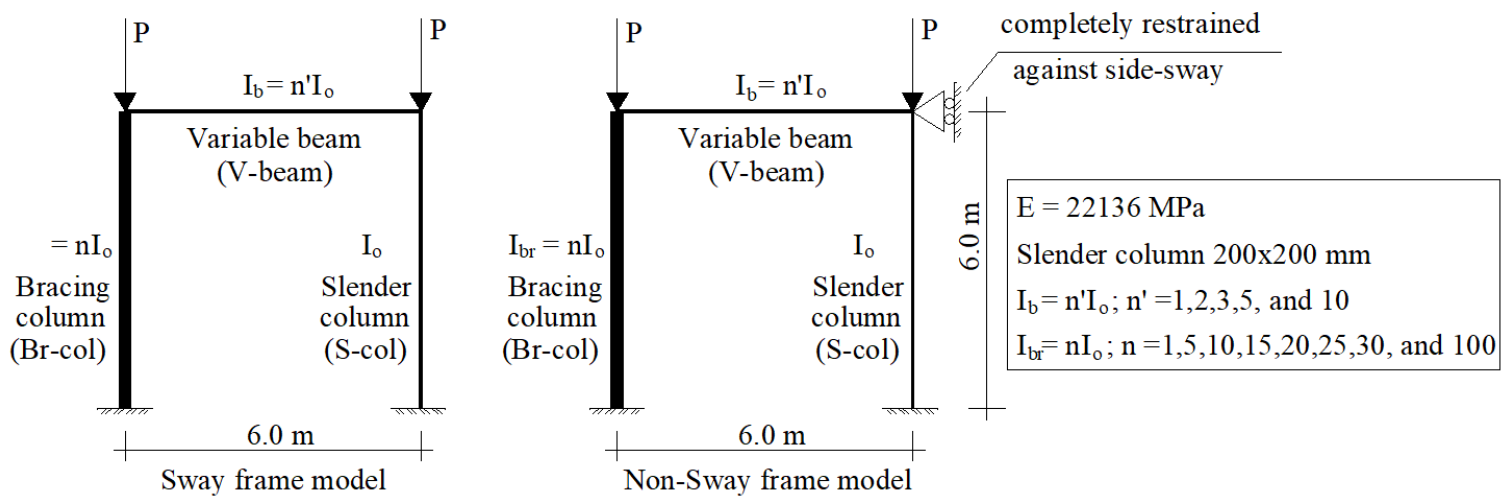

Figure 2. One-story, one bay-frame model.
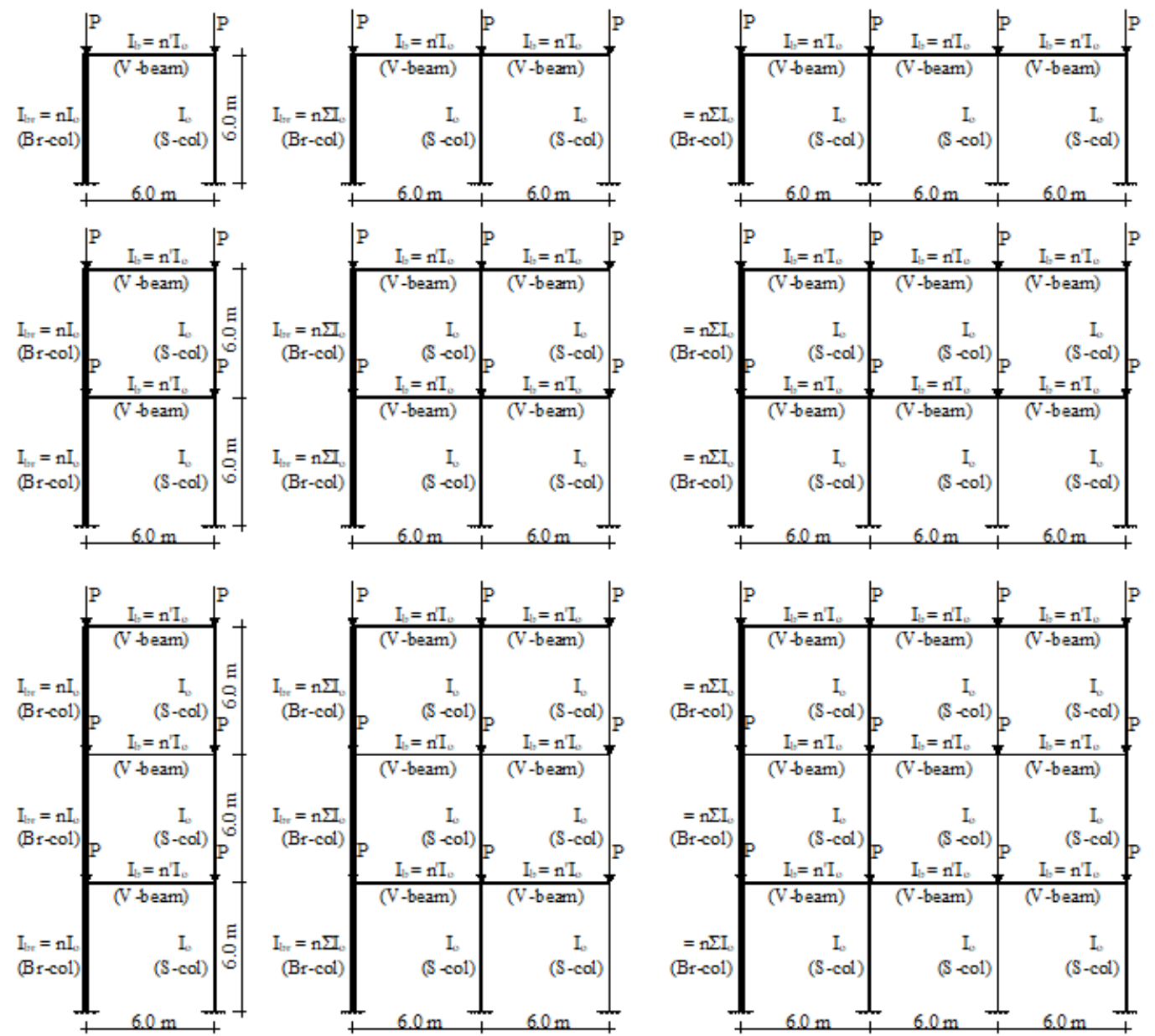

Figure 3. Multi-stories, multi-bays frame models. 


\section{RESULTS AND DISCUSSIONS}

Based on the obtained results, the required bracing limit and the effective length factors of all studied frames are summarized in Tables 1,2, and 3. The effective length factor $\mathrm{K}$ of slender columns was calculated by substituting the critical buckling load, obtained from buckling analysis, in Equation 1 (Euler's equation).

Table 1. Required bracing limit and effective length factors for the one-story frames.

\begin{tabular}{|c|c|c|c|c|c|c|c|}
\hline \multirow[b]{2}{*}{$n^{\prime}=\left(I_{b} / I_{o}\right)$} & \multicolumn{3}{|c|}{ Required bracing limit $n=\left(I_{b r} / I^{0}\right)$} & \multicolumn{4}{|c|}{ Effective length factor (K) } \\
\hline & $\begin{array}{l}\text { One bay } \\
\text { frame }\end{array}$ & $\begin{array}{c}\text { Two bays } \\
\text { frame }\end{array}$ & $\begin{array}{c}\text { Three bays } \\
\text { frame }\end{array}$ & $\begin{array}{c}\text { Buckling } \\
\text { analysis }\end{array}$ & $\begin{array}{c}\text { ANSI/AISC } \\
360-16\end{array}$ & ACI $318-14$ & $\begin{array}{c}E C P 203-2018 \\
\text { and BS 8110- } \\
97\end{array}$ \\
\hline 1 & 18.8 & 13.87 & 12.78 & 0.59 & 0.91 & 1.19 & 1.30 \\
\hline 2 & 18.67 & 13.76 & 12.50 & 0.56 & 0.85 & 1.10 & 1.23 \\
\hline 3 & 18.48 & 13.53 & 12.39 & 0.55 & 0.84 & 1.07 & 1.20 \\
\hline 5 & 17.37 & 13.18 & 12.12 & 0.53 & 0.82 & 1.04 & 1.19 \\
\hline 10 & 13.39 & 9.67 & 9.43 & 0.52 & 0.81 & 1.02 & 1.17 \\
\hline
\end{tabular}

Table 2. Required bracing limit and effective length factors for the two-stories frames.

\begin{tabular}{|c|c|c|c|c|c|c|c|}
\hline \multirow[b]{2}{*}{$n^{\prime}=\left(I_{b} / I_{o}\right)$} & \multicolumn{3}{|c|}{ Required bracing limit $n=\left(\mathbf{I}_{b r} / \mathbf{I}^{0}\right)$} & \multicolumn{4}{|c|}{ Effective length factor (K) } \\
\hline & $\begin{array}{c}\text { One bay } \\
\text { frame }\end{array}$ & $\begin{array}{c}\text { Two bays } \\
\text { frame }\end{array}$ & $\begin{array}{c}\text { Three bays } \\
\text { frame }\end{array}$ & $\begin{array}{c}\text { Buckling } \\
\text { analysis }\end{array}$ & $\begin{array}{c}A N S I / A I S C \\
360-16\end{array}$ & ACI 318-14 & $\begin{array}{c}\text { ECP } 203-2018 \\
\text { and BS 8110- } \\
97\end{array}$ \\
\hline 1 & 74.41 & 25.00 & 22.73 & 0.60 & 1.01 & 1.34 & 1.45 \\
\hline 2 & 29.20 & 24.10 & 21.20 & 0.56 & 0.91 & 1.19 & 1.30 \\
\hline 3 & 24.85 & 23.05 & 19.83 & 0.56 & 0.88 & 1.14 & 1.25 \\
\hline 5 & 19.39 & 19.03 & 17.76 & 0.53 & 0.85 & 1.08 & 1.21 \\
\hline 10 & 13.96 & 12.68 & 12.68 & 0.52 & 0.82 & 1.04 & 1.18 \\
\hline
\end{tabular}

Table 3. Required bracing limit and effective length factors for the three-stories frames.

\begin{tabular}{|c|c|c|c|c|c|c|c|}
\hline \multirow[b]{2}{*}{$n^{\prime}=\left(I_{b} / I_{0}\right)$} & \multicolumn{3}{|c|}{ Required bracing limit $\mathbf{n}=\left(\mathbf{I b r}_{\mathbf{b r}} / \mathbf{I}^{\circ}\right)$} & \multicolumn{4}{|c|}{ Effective length factor (K) } \\
\hline & $\begin{array}{l}\text { One bay } \\
\text { frame }\end{array}$ & $\begin{array}{c}\text { Two bays } \\
\text { frame }\end{array}$ & $\begin{array}{c}\text { Three bays } \\
\text { frame }\end{array}$ & $\begin{array}{c}\text { Buckling } \\
\text { analysis }\end{array}$ & $\begin{array}{c}\text { ANSI/AISSC } \\
360-16\end{array}$ & ACI $318-14$ & $\begin{array}{c}\text { ECP 203-2018 } \\
\text { and BS 8110- } \\
97\end{array}$ \\
\hline 1 & 88.21 & 76.34 & 53.40 & 0.62 & 1.01 & 1.34 & 1.45 \\
\hline 2 & 81.59 & 66.70 & 36.20 & 0.58 & 0.91 & 1.19 & 1.30 \\
\hline 3 & 73.34 & 54.59 & 29.46 & 0.56 & 0.88 & 1.14 & 1.25 \\
\hline 5 & 29.05 & 27.16 & 26.25 & 0.54 & 0.85 & 1.08 & 1.21 \\
\hline 10 & 18.67 & 16.73 & 17.77 & 0.52 & 0.82 & 1.04 & 1.18 \\
\hline
\end{tabular}

\subsection{Effect of degree of lateral bracing on the behavior of slender columns}

The results of the analysis given in Tables 1 to 3 indicated that increasing the stiffness of the bracing column, i.e., the increasing degree of lateral bracing $\left(\mathrm{I}_{\mathrm{br}} / \mathrm{I}_{\mathrm{o}}\right)$ increases the critical buckling load for the slender column until this load reaches approximately the buckling load for the corresponding column in a non-sway model. The minimum values of the bracing limit required to restrain the slender column against the side-sway vary according to the number of bays, number of stories, and stiffness of the connecting beam. Although, a value of $\mathrm{I}_{\mathrm{br}} / \mathrm{I}_{\mathrm{o}}=18.8$ is sufficient to restrain the slender column in the one-story, one-bay frame model, the required value for three-stories, one-bay frame model is increased to 88.2. This great effect for the number of stories on the behavior of slender columns was obtained for the columns connected with the small stiffness of the connecting beams. This effect may be explained by the increase of 
the buckling length of the slender column with the increase of the number of stories. Similarly, for models with beams of small stiffness $\left(\mathrm{I}_{b} / \mathrm{I}_{o}<5\right)$, increasing the number of bays for the frame models decreases the degree of bracing required to restrain the slender column. For example, for $\mathrm{I}_{\mathrm{b}} / \mathrm{I}_{\mathrm{o}}=1.0$ in the two-stories, one-bay frame model, the required bracing limit was 74.4 while the above limit was only 22.7 for the two-stories, three-bays frame model.

MacGregor [1] stated that the structure can be considered as a non-sway structure if the stiffness of the bracing column is six times that of the slender column. This limit is conservative when compared to the limits obtained from the currently obtained results and the results of Fawzy [16]. Also, Equations 4 and 5 recommended by the Egyptian Code (ECP 203-2018) [4], for the classification of columns as sway or non-sway, gives very conservative values when compared to the results of the analysis presented in this study. For example, for the one-story, one-bay frame model the analysis gives a value of 18.8 for $\mathrm{I}_{\mathrm{br}} / \mathrm{I}_{\mathrm{o}}$ while the limit obtained by the Egyptian Code is 85 .

\subsection{Effect of beam stiffness on the required bracing limit}

The results obtained from the analysis indicated that the increase of the stiffness of the beam connecting the slender column at the top decreased the bracing limit required to consider the structure as a non-sway one. The bracing limit is defined as the ratio of the bracing column inertia $\mathrm{I}_{\mathrm{br}}$ to that for the slender column $\mathrm{I}_{\mathrm{o}}$. For the one-story, one-bay frame model, increasing the ratio of the beam inertia to that for the slender column $\left(\mathrm{I}_{b} / \mathrm{I}_{\mathrm{o}}\right)$ from 1.0 to 10 decreased the required bracing limit from 18.8 to 13.4 (i.e., a reduction of about 28.7\%). Figure 4 displays the relationship between the ratio of the beam stiffness $\left(\mathrm{I}_{\mathrm{b}} / \mathrm{I}_{\mathrm{o}}\right)$ and the degree of lateral bracing for all the cases studied. The figure indicates that for stiff beams (i.e., $I_{b} / I_{o} \geq 5$ ), the change in the values of the required bracing limit is small. It should be noted that the effect of beam stiffness, on the classification of the structure as non-sway or sway, is not included in most building codes.

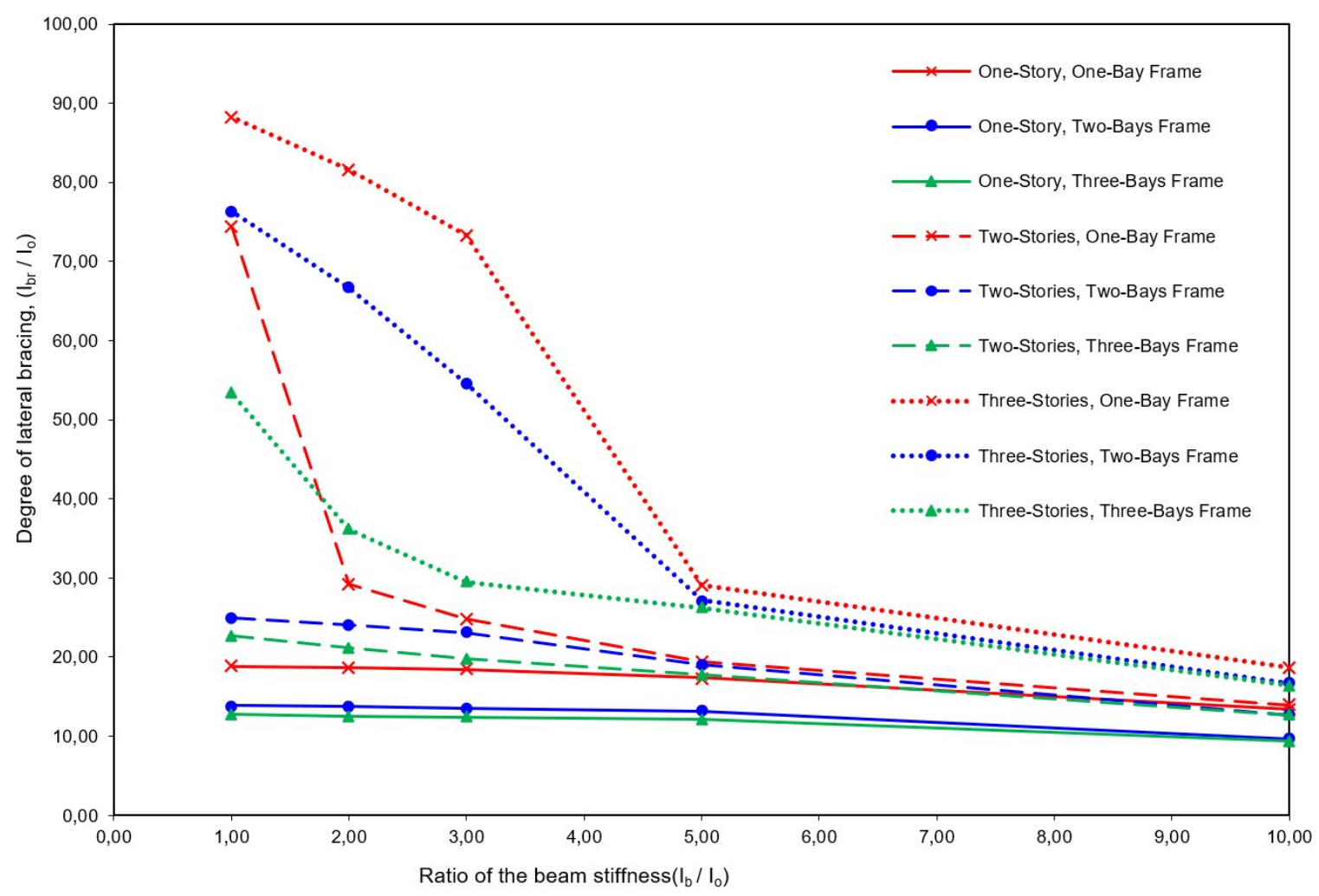

Figure 4. Relation between the ratio of the beam stiffness $\left(\mathrm{I}_{\mathrm{b}} / \mathrm{I}_{\mathrm{o}}\right)$ and the degree of lateral bracing. 


\subsection{Effective length factor}

Figure 5 presents the relation between the effective length factor $(\mathrm{K})$ and the ratio of the beam stiffness $\left(\mathrm{I}_{\mathrm{b}} / \mathrm{I}_{\mathrm{o}}\right)$. Generally, with the increase of moment of inertia for the bracing columns; $\mathrm{I}_{\mathrm{br}}$, the effective length factor decreases, and the structure changes from a sway-structure $(K>1.0)$ to a non-sway one $(K<1.0)$. It should be noted that most building codes do not consider the degree of lateral bracing when calculating the effective length factor. The equations recommended by building codes give only two values for the effective length factor; one for non-sway frames and the other for sway frames and neglect the fact that most structures are to be considered partially braced. However, the best results for the effective length factor from the considered building codes were obtained using Equation 13 defined by ANSI/AISC 360-16. The effect of changing the moment of inertia of the connecting beam on the value of the effective length factor was small. This effect was large with increasing the number of stories and/or the number of bays, and for the bracing columns with inertia $\mathrm{I}_{\mathrm{br}} / \mathrm{I}_{\mathrm{o}}>1.0$. According to the Egyptian Code (ECP 203-2018) [4], the value of the rotational restraints at column joint $(\Psi)$ should not be taken less than 1.0. However, in this study, the value of $\Psi$ was changed from $0.1\left(\mathrm{I}_{\mathrm{b}} / \mathrm{I}_{\mathrm{o}}=10\right)$ to $1.0\left(\mathrm{I}_{\mathrm{b}} / \mathrm{I}_{\mathrm{o}}=1.0\right)$. In addition, the Egyptian Code gives a minimum value of $\mathrm{K}=0.7$ for a braced (non-sway) column, while the present analysis gives values for the effective length factor $\mathrm{K}=0.5$ to 0.6 when the slender columns were restrained against side-sway.

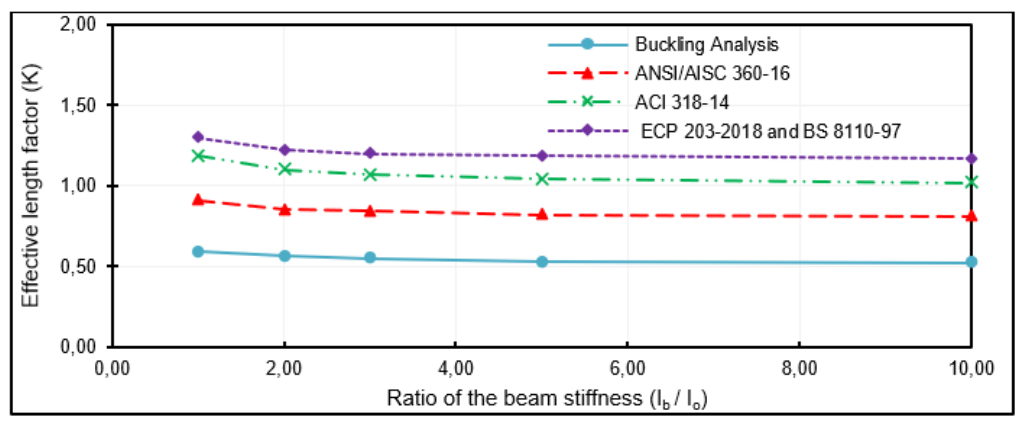

(a)

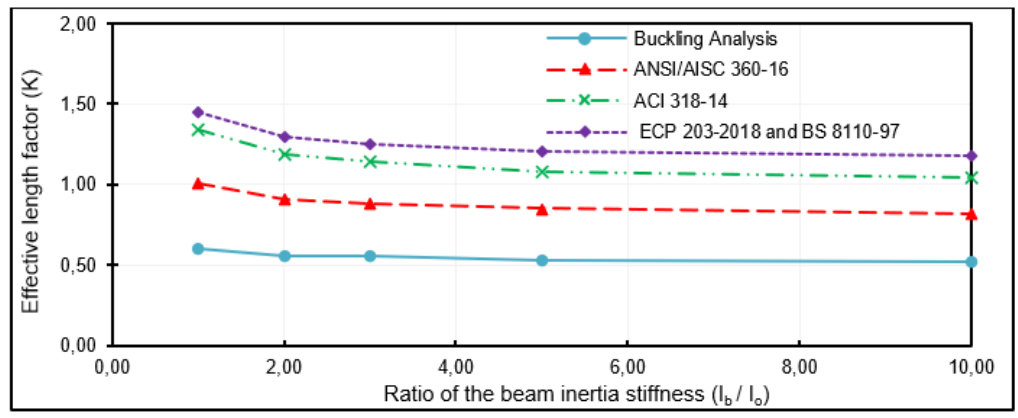

(b)

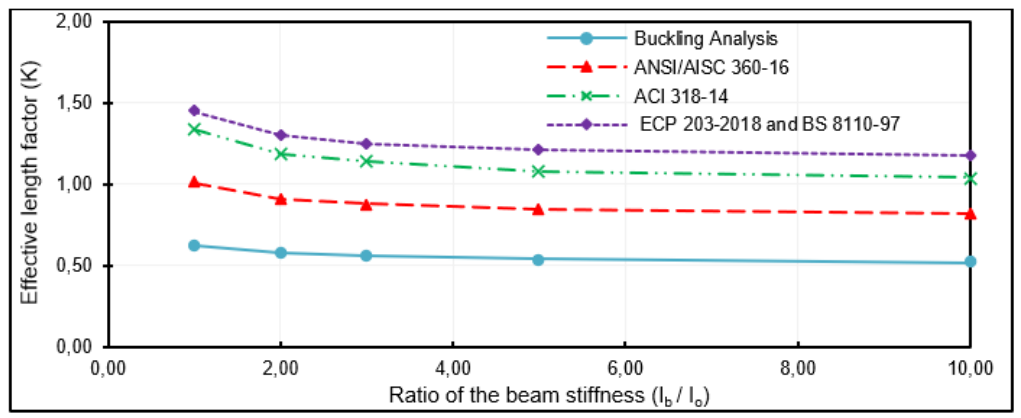

(c)

Figure 5. Relation between the effective length factor and the ratio of the beam stiffness $\left(\mathrm{I}_{\mathrm{b}} / \mathrm{I}_{\mathrm{o}}\right)$. a) one-story frames; b) twostories frames; c) three-stories frames. 


\section{CONCLUSIONS}

The main purpose of this paper was to study the behavior of slender reinforced concrete columns existing in sway and non-sway structures. The stability of slender columns was studied and the required limits for the lateral bracing were determined. The Finite Element program ANSYS was used to perform buckling analysis, linear analysis, and geometric nonlinear analysis for the different frame structural models. Many variables were studied affecting the stability of the structures. These variables were the beam stiffness connecting to the slender columns, the stiffness of the bracing column, and the number of bays and stories in the structural frame model. From the results obtained from the theoretical work presented in this study, the following conclusions may be drawn:

- The minimum value of the bracing limit required to restrain the slender column against the side-sway depends on the number of stories, number of bays, and stiffness of the connecting beam. Effect of beam stiffness was clearly observed for beams with stiffness ratio $\mathrm{I}_{\mathrm{b}} / \mathrm{I}_{\mathrm{o}}$ more than 2 .

- Increasing the number of stories increases the required degree of lateral bracing. However, increasing the number of bays decrease the degree of lateral bracing.

- The equation recommended by the Egyptian Code for the classification of the columns as sway or non-sway gives very conservative values when compared to the present analyses.

- Most building codes give only two values for the effective length factor; one for non-sway columns and the other for sway columns and neglect the fact that most structures in practice are to be considered partially braced. Also, the Egyptian Code recommends conservative values for the effective length factor for both braced and unbraced columns.

\section{REFERENCES}

[1] J. MacGregor, "Design of slender columns revisited," Struct. J., vol. 90, no. 3, pp. 302-309, 1993.

[2] American Concrete Institute, Building Code Requirements for Structural Concrete (ACI 318-14) and Commentary on Building Code Requirements for Structural Concrete, ACI 318R-14, 2014.

[3] J. G. MacGregor and S. E. Hage, "Stability analysis and design of concrete frames," J. Struct. Div., vol. 103, no. 10, pp. 1953-1970, 1977.

[4] Housing and Construction National Research Center, Egyptian Code for Design and Construction of Reinforced Concrete Structures, ECP203-2018, 2018.

[5] British Standards Institution, Structural Use of Concrete, Part 1: Code of Practice for Design and Construction, BS 8110-97, 1997.

[6] W. Cranston, Analysis and Design of Reinforced Concrete Columns (Research Report 20). London: Cement and Concrete Association, 1972.

[7] R. W. Furlong, "Column slenderness and charts for design," ACI J. Proc., vol. 68, no. 1, pp. 9-19, 1971.

[8] American Institute of Steel Construction, Specification for Structural Steel Buildings, ANSI/AISC 360-16, 2016.

[9] J. D. Aristizabal-Ochoa, "Story stability and minimum bracing in RC framed structures: a general approach," ACI Struct. J., vol. 92 , no. 6, pp. 735-744, 1995.

[10] J. D. Aristizabal-Ochoa, "Story stability of braced, partially braced, and unbraced frames: classical approach," J. Struct. Eng., vol. 123, no. 6, pp. 799-807, 1997.

[11] J. Hellesland and R. Bjorhovde, "Improved frame stability analysis with effective lengths," J. Struct. Eng., vol. 122, no. 11, pp. 1275$1283,1996$.

[12] A. Bendito, M. L. Romero, J. Bonet, P. Miguel, and M. Fernandez, "Inelastic effective length factor of nonsway reinforced concrete columns," J. Struct. Eng., vol. 135, no. 9, pp. 1034-1039, 2009.

[13] H. Ma, L. Ye, and L. Lin, "A Study on Effective Length of Slender Column with Elastic Restraints," Procedia Eng., vol. 210, pp. 228-234, 2017.

[14] M. A. Farouk, "Second-order analysis in braced slender columns part I: approximate equation for computing the additional moments of slender columns," JES: J. Eng. Sci., vol. 45, no. 2, pp. 118-141, 2017.

[15] A. R. Marí and J. Hellesland, "Lower slenderness limits for rectangular reinforced concrete columns," J. Struct. Eng., vol. 131, no. 1, pp. 85-95, 2005.

[16] A. Fawzy, "Study of column slenderness in reinforced concrete buildings," M.S. thesis, Dept. Struct. Eng., Fac. Eng., Alexandria Univ., Egypt, 2002.

[17] M. Khuntia and S. K. Ghosh, "Flexural stiffness of reinforced concrete columns and beams: analytical approach," ACI Struct. J., vol. 101, no. 3, pp. 351-363, 2004.

[18] M. Khuntia and S. K. Ghosh, "Flexural stiffness of reinforced concrete columns and beams: experimental verification," ACI Struct. $J .$, vol. 101, no. 3, pp. 364-374, 2004. 
[19] ANSYS Inc., ANSYS Theoretical Manual (for ANSYS Revision 8.04). Canonsburg, PA: ANSYS Inc., 1998.

Author contributions: MGA: methodology, writing, data curation, formal analysis; MES and SMA: conceptualization, supervision, formal analysis.

Editors: Mauro de Vasconcellos Real, Guilherme Aris Parsekian. 